\title{
Cultural Studies in Portuguese: Where Next?
}

\section{Hilary Owen}

Is it anachronistic or utopian to talk about "New Perspectives on Cultural Studies in Portuguese" in the third millennium? The conference of this title, which gave rise to the present collection, was held in May 2000 at the Institute of Romance Studies, University of London, thanks to Instituto Camões and Calouste Gulbenkian Foundation funding. As Paulo de Medeiros indicates, the inspiration for the project is neither the "belated" application to Portuguese Studies of Anglo-American models of Cultural Studies nor a superceding of "traditional" literary studies born of an ideological struggle to the death. Rather it seeks to ask how the insights of cultural studies and the theories and practices informing it, can be usefully deployed in the study of Portuguese cultural production, in what Boaventura de Sousa Santos terms in his contribution to this volume, the "time/space" of the Portuguese language. A key temporal orientation point in this mapping of Portuguese language/space is perhaps inevitably the 25 April as "ponto de ruptura" in Portuguese literature's perceptions of itself. If cultural studies has always defined itself, on one level, as the necessary "other" of literary studies, then anti-canonical questions of margin and center, high and low, elite and popular culture, were posed with particular intensity in the immediate post-revolutionary context of literary debate. The interventions that writers, journalists and critics made to the $1^{\circ}$ Congresso dos Escritores Portugueses, which took place in Lisbon in May 1975, at the beginning of the famous "verão quente," provide some usefully indicative insights in this respect.

The generation of the revolution were certainly moulded by the shared experience of state censorship and their resistance to it. However, they adopted a wide range of positions on the problematics of literature, variously informed by their intersecting relations with class struggle, the imperatives of cultural revolution, African decolonisation, and, to a lesser extent, sex and gender politics. For many participants in this $1^{\circ}$ Congresso, the question of culture was posed in relation to the politics of literacy and the political responsibilities of the intellectual as mediator. This also, conversely, raised the issue of the academic validation of oral, "popular" and marginal cultures. Arnaldo Saraiva, for example, warns against the devaluing of "popular" cultures, pointing out:

A teoria de literatura sempre teve dificuldade em definir o seu objecto. Teóricos, críticos, escritores, leitores, raremente têm encontrado fórmulas capazes de explicarem correctamente o que é a literatura.

Where Saraiva stressed the importance of bringing oral popular cultures into the purview of serious critical study, others such as Maria Alzira Seixo focused on the need to improve literacy at all levels of society as a fundamental precondition for the national regeneration of literature. Pursuing this at a grassroots level, Urbano Tavares Rodrigues's "Escritores e Revolução" made a powerful appeal for the "liberdade do leitor, do leitor potencial, e suboperário, o pequeno empregado, o camponês, que não possuem nem poder 
acquisitivo, nem acesso a cultura." The MFA pursuit of cultural revolution through its "Campanha de Dinamização" following 25 April enjoyed a short-lived career, fostering cultural initiatives among the workers. The counter-coup of 25 November 1975 marks the moment that Eduarda Dionísio refers to as the "inversão da marcha da História" (242), with the end of the "verão quente." The Communist Party's subsequent marginalisation in the political process witnessed the gradual decline, transformation or institutional assimilation of the cultural and literary initiatives of the radical left.

The progressive abandonment of specifically Communist and radical left agendas marks out an identifiable historical trajectory, precisely and usefully tracked by Eduardo Dionísio's Títulos, Acções e Obrigações, through the changes in state cultural policy and practice from 1975 onwards. In this context, it becomes possible to trace, according to a model of prematurely truncated teleology, specific points marking Portugal's complex and multiple "cultural turns" as well as the subsequent relationship to the politics of memory and selfrepresentation. This act of mapping also facilitates an exploration of the institutional intellectual legacies of this period, visible in the selective and short-lived politicisation of academic critical knowledge bases swiftly reterritorialised into disciplines that proved resistant to the interdisciplinarity of cultural studies. As Graça Abranches has remarked in contextualising the history of Women's Studies in Portuguese higher education, "in the aftermath of the 1974 Revolution [...] Marxist theory, class and 'race' problematics were taken up within the universities - to vanish gradually and discretely as the democratic regime became 'consolidated' in the eighties" (8). Where does sourcing these apparent institutional impasses leave our present consideration of cultural studies in relation to the time/space of Portuguese language?

As Stuart Hall has indicated, a prevailing myth of British cultural studies concerns the belief in a "prior moment when cultural studies and Marxism represented a perfect theoretical fit" (100). As an ideological variant on "creation myth" this belief is even less helpful in the Portuguese case, where it becomes a failed or always deferred point of origin harking back to the defeat of the radical left in the revolutionary crisis. Departing, instead, from Hall's assertion that "cultural studies has no simple origins" and should therefore be considered a "discursive formation in Foucault's sense" (100), the present collection focuses rather on the micro-histories fissuring the "marcha da História" (Dionísio 242). In this sense, cultural studies works rather as a theoretical practice of strategic inter/ruption, exploring the ongoing power investments of specific cultural representations. The description of cultural studies as Foucauldian discursive formation offers, then, a series of vitally anti-epistemic critical practices foregrounding a time/space of disruption and self-reflexivity, underpinning Hall's dialogic practice of theory as a reading in/tension. In this sense Hall reaffirms the Gramscian concept of "conjunctural knowledge" whereby theory is "a set of contested, localized, conjunctural knowledges which have to be debated in a dialogical way" (108-9).

In the spirit of contestation and debate, the present objects of study and their readings effectively perform a dialogue between the practice of cultural studies as an interdisciplinary theoretical discourse and localized studies of specific cultural practices. Best described, perhaps, as a collection of cultural studies "case histories," they engage with a number of interrelated issues, such as the politics of embodiment, the structuring of shifting national identifications, representations of cultural memory, the lasting effects of state censorship, and the bearing of historical witness. The Estado Novo looms large in this collection. Its propagandist technologies, its subsequent repositionings and counter-images in national memory/space and its cultural continuities with post-revolutionary democratic Portugal, provide the focal point for many of the contributions. The following description of contents highlights some of the points of connection, contestation and disjuncture between the different papers. 
Kimberley DaCosta Holton's contribution analyzes the representation of fado in the 1994 Fado exhibition at Lisbon's Museu Nacional de Etnologia. Exploring the staged interplay of sound, text and image, in the museum's alternation of aural and visual, she demonstrates how it produced both sensually embodied and reflective analytical encounters with fado music as a multiply addressed national memory/space. José Ornelas's article explores embodiment from a rather different angle, focussing on the use that Portuguese fascism made of the ideal, desexualised body and its often dissident inscription in the work of José Saramago and Teolinda Gersão. In Maria Manuel Lisboa's readings of Paula Rego's abortion pastels, the body figures prominently as the locus of power, pain and pleasure circulating in Rego's implied masculine gaze, ironically underwritten by canonical images from western maternalist art, and suggesting a continuity in Catholic power investments for pre- and post-revolutionary culture. Also working in the field of visual culture, Ellen Sapega switches focus to look at urban landscapes and their representations, exploring the resistance of national pedagogical image-making, through the subversive effects of the counter-image, exemplified to varying degrees in her two case histories, the Alcântara station wall murals by José de Almada Negreiros and post-1974 photography of the Padrão dos Descobrimentos. The photographic image forms the basis for Paulo de Medeiros's analysis of Portuguese Colonial War photography demonstrating the effects of counter-imaging to be derived from the pictures' cynical manipulations of surface banality in representations of extreme violence, as well as their ironically unconscious subtexts of technological pre-modernity. Moving forward a decade, my own paper engages with the discontents of Mozambique in the 1980s, discussing Lina Magaia's war testimonial Dumba Nengue and its renegotiations of maternalist imagery in Frelimo discourses of national solidarity as metonymic. The vexed question of the (post)colonial in the time/space of Portuguese language is central to Boaventura de Sousa Santos's article, in which he painstakingly deconstructs the manicheism of the Prospero/Caliban topos, to detail the specific histories that complicate the Portuguese relationship to "dominant" postcolonial theory. At the same time, however, he keeps in view the elite investments at stake in refusing Portugal any positionality at all in delineating (post)colonial fields of power. Maintaining this necessary focus on the constant shifting of investments at stake, no paper in the present volume claims to offer a definitive standpoint on cultural studies, much less a rallying cry to the barricades against literature. Rather it is hoped that the collection as a whole will produce a range of simultaneously conand dis- junctural readings, enabling cultural studies in the teaching time/spaces of Portuguese language to maintain a much-needed critical impetus of political value and practical use.

\section{WORKS CITED}

Abranches, Graça. “'On what terms shall we join the procession of educated men?' Teaching Feminist Studies at the University of Coimbra." Coimbra: Oficina do CES. Centro de Estudos Sociais. Vol. 125 (July 1998): 1-21.

Dionísio, Eduarda. Títulos, Acções e Obrigações. Sobre a Cultura em Portugal. 1974-1994. Lisbon: Edições Salamandra, 1993.

Hall, Stuart. "Cultural Studies and its Theoretical Legacies." Ed. Simon During. The Cultural Studies Reader. London: Routledge, 1993. 97-109. 
Rodrigues, Urbano Tavares. "Escritores e Revolução." $1^{\circ}$ Congresso dos Escritores Portugueses. 10-11 de Maio de 1975. Associação da Biblioteca Nacional, Lisboa. Unpublished proceedings. N. pag. File no. 3,293 at the Centro de Documentação 25 de Abril, University of Coimbra.

Saraiva, Arnaldo. "As duas literaturas." $1^{\circ}$ Congresso dos Escritores Portugueses. For full reference see above.

Seixo, Maria Alzira. "Literatura, Processo Revolucionário e Comunicação." $1^{\circ}$ Congresso dos Escritores Portugueses. For full reference see above. 